JOURNAL OF SECURITY AND SUSTAINABILITY ISSUES

ISSN 2029-7017 print/ISSN 2029-7025 online

2021 Volume 11

https://doi.org/10.47459/jssi.2021.11.39

\title{
THE IMPACT OF RUSSIAN POLICY ON SAUDI ARABIA IN TERMS OF ECONOMY SECURITY
}

\author{
Pawel Kępa $^{1}$, Bartosz Kozicki ${ }^{2}$ \\ ${ }^{1}$ Rzeszów University of Technology, Poland \\ ${ }^{2}$ Military University of Technology, Poland

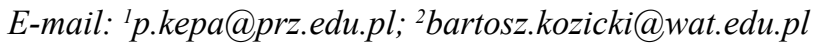

Received 18 March 2021; accepted 10 June 2021; published 30 June 2021

\begin{abstract}
The study attempts to present the impact of Russian policy on Saudi Arabia in terms of economic security. Analyses of primary data on the quantitative states of the possessed oil and gas resources and their annual consumption, as well as the state of essential armaments of Russia and Saudi Arabia were carried out and evaluated. As a result of the analysis of the literature of the research, it was observed that the potential of Russian-Saudi military cooperation is unrealized. One of the goals of Russian policy is to seek to limit the influence of both Saudi Arabia and the United States in the Middle East region. This limitation allows Saudi Arabia itself to not dictate world oil prices. The United States, on the other hand, due to its huge demand for oil, is forced to pursue such a policy in order to be guaranteed an adequate price and continuity of supply to meet its oil needs now and in the future.
\end{abstract}

Keywords: multivariate comparative analysis; energy policy; Russia; Saudi Arabia; Covid-19; economic security

Reference to this paper should be made as follows: Kępa, P., Kozicki, B. 2021. The impact of Russian policy on Saudi Arabia in terms of economy security. Journal of Security and Sustainability Issues, 11, 435-440. https://doi.org/10.47459/jssi.2021.11.39

JEL Classifications: B29

Additional disciplines: political sciences and administration, law

\section{Introduction}

The paper formulates a research problem, which focuses on the impact of Russian policy on Saudi Arabia in terms of influence on oil prices - through the impact of its own military potential, taking into account the provision of economic security. In addition to the research problem, the purpose of the work is outlined.

The main objective of the study is to attempt to examine the impact of Russian policy on Saudi Arabia through its attempt to dictate oil prices and the military policy it pursues in the Middle East region. For the research problem and objective of the paper thus adopted, the research hypothesis is outlined: Russia interacts with Saudi Arabia in the aspect of dictating oil prices in dynamic terms. The subject of the study will be the volumes of oil and gas resources and consumption, as well as the essential armaments of Saudi Arabia and Russia. While the subject will be the countries that possess and consume the most oil and gas in the world, including Saudi Arabia and Russia.

The study conducted a literature review on the capabilities and policies of Russia and Saudi Arabia. The method of multidimensional comparative analysis was applied. Clustering of the available data was performed and analyzed. 


\section{Literature Analysis}

A critical analysis of the literature shows that Russia has been conducting increased political activity in the Middle East for the past several years. One of the goals of Russian policy is to reduce the dominance of Saudi Arabia in the region (Legucka, 2017). Saudi Arabia's dominance stems from its massive oil and gas reserves. Its weakening will result in taking away the exclusive power to dictate the level of global oil prices. The factor that makes Saudi Arabia fear Russia's policy is the military aspect. Russia has nuclear weapons and possesses huge amounts of armaments. Basically, it can be assumed that it is not afraid of other countries, which was manifested by the annexation of Crimea in 2014. The paper attempts to analyze and evaluate primary data on the size of oil, gas and essential armaments resources and consumption of Saudi Arabia and Russia.

In 2020, an infectious disease named COVID-19 emerged worldwide, with the first case of the disease reported in Wuhan, China (Grochot, 2020; Zhu, Zhang, Wang, et al., 2020). On March 11, 2020, a COVID-19 pandemic was declared (Satomi, et al., April 2020). Since then, numerous restrictions have been placed on the world including travel restrictions, wearing masks, and using disinfectants. The situation has led to widespread concern (Matuka, September 2020). The COVID-19 pandemic since March 2020 has caused global oil price declines.

Russia's military policy in the region of the Middle Eastern countries is carried out in order to ensure its own economic security in terms of the appropriate level of oil prices. In the literature, economic security is interpreted as the certainty of survival associated with access to markets, financial resources, which guarantees the stable development of entities (Nurzynska, 2016, p. 22).

In the study, multivariate comparative analysis was used for research. This analysis refers to a group of statistical methods by which two or more variables describing the dependent variable are compared (Luniewska, 2006; Kozicki, 2018). The methods used were clustering by country and essential armament. Comparative methods allow to determine which elements of the group are similar to each other in terms of the adopted criteria (Nermend, 2017, p. 151). The application of comparative analysis made it possible to detect regularities, which became the premises for the formulation of the summary and conclusions.

\section{Multidimensional data analysis of oil, natural gas, and military capabilities of Russia and Saudi Arabia}

The research began with a compilation of primary data (Figure 1) on the countries' holdings of the world's largest oil reserves (countries with more than 10,000,000,000 barrels).

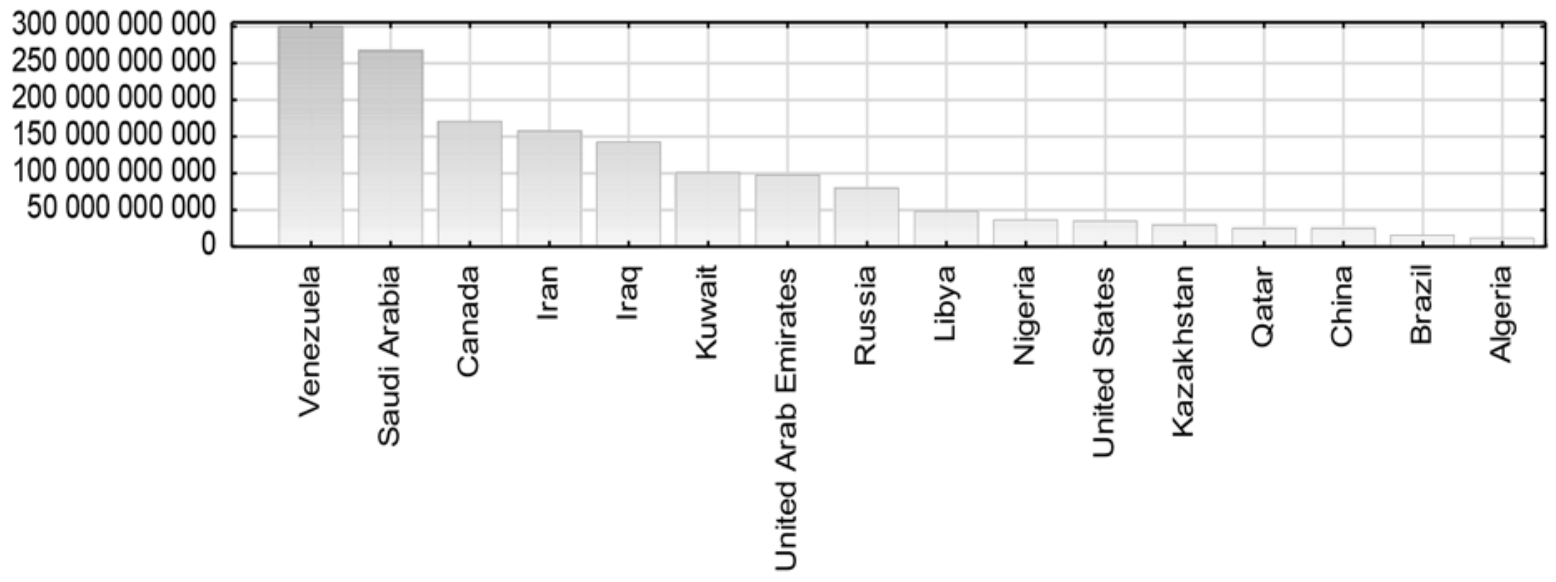

Figure 1: Bar chart of primary data on the world's largest oil reserves by country in barrels (countries above 10,000,000,000 barrels) 
The data in Figure 1 shows that the world's largest oil reserves are in Venezuela. It holds about 299,953,000,000 barrels of oil, or 18.3 percent of the total reserves. In second place is Saudi Arabia, which has about 266,578,000,000 barrels of oil, or 16.2 percent of the world's reserves. It should be emphasized that Middle Eastern countries such as Saudi Arabia, Iran, Iraq, Kuwait and the United Arab Emirates together hold about $766,477,000,000$ or 46.44 percent of the world's oil reserves. Russia, on the other hand, has about $80,000,000,000$ barrels of oil, which is about 4.8 percent of the world's reserves. To sum up, the largest oil reserves are in the Middle Eastern countries and it is these countries that determine the oil price dynamically. Despite its large oil resources, Russia is not in a position to dictate world prices, but only to influence them through its policy.

The next step of the research will be to analyze the largest oil consumption by country during the year (2016) in barrels.

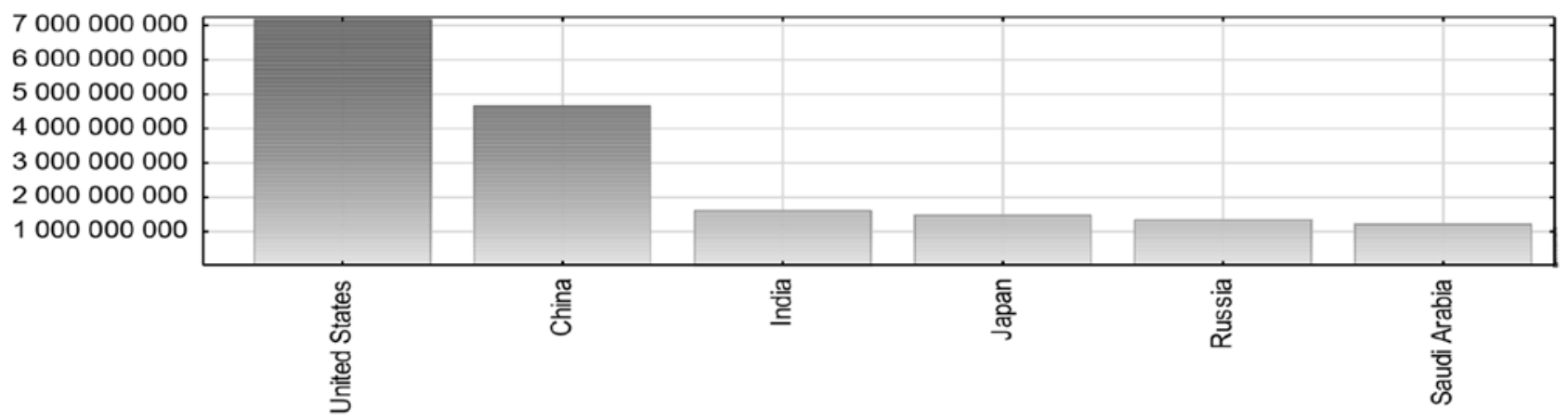

Figure 2: Bar chart of primary data on countries that consume the most oil in barrels per year

Source: own compilation based on data extracted from the website: https://data.worldbank.org/ [as of 10/03/2020].

The data presented in Figure 2 show that the world leader in oil consumption on an annual basis is the United States. In 2016, they consumed about 7,185,859,755 barrels of oil, or 20.3 percent of the consumption of all the countries in the world in the time frame considered. They can be self-sufficient in the aspect of oil for about five years. In second place is China, which consumed about 4,668,916,845 in 2016, or 13.2 percent of the consumption of all countries of the world in the time frame under consideration. Like the United States, China is able to be self-sufficient in the oil aspect for five years. Russia is in fifth place in the ranking. It consumes about 1,325,419,755 per year, which is about 5.42 times less than the United States. If Russia consumed only its resources and did not sell to other countries, it would be able to use them for about 60 years.

In sixth place in terms of oil consumption is Saudi Arabia. In 2016, it consumed about 1,205,230,000, or 3.4 percent of all countries considered. Saudi Arabia could be self-sufficient in the aspect of oil for about 222 years.

Considering the huge oil reserves of Saudi Arabia, Russia must conduct a joint policy with it in the aspect of shaping world oil prices favorable to it. The total oil resources should be sufficient for the needs presented by the economies of individual countries for about 56 future years, assuming that the consumption will be the same as in the considered year 2016 and will not show an increasing or decreasing trend.

Another interesting raw material is natural gas. Figure 3 summarizes primary data on the world's largest natural gas reserves by country. 


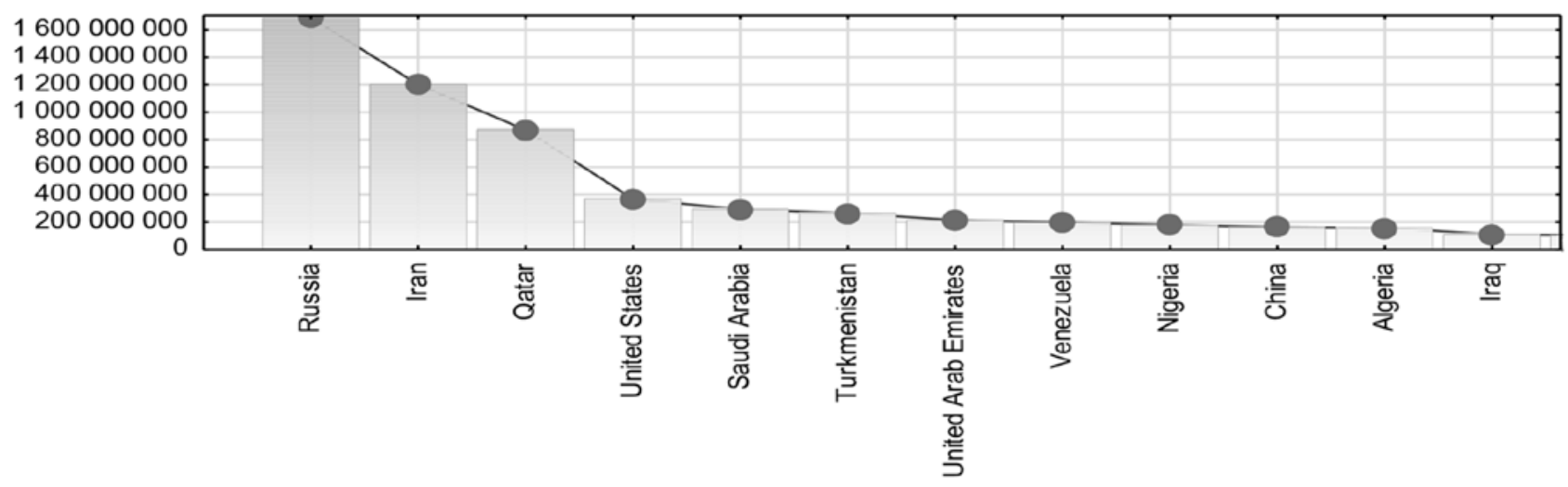

Figure 3. Bar chart of primary data on the world's largest gas reserves in million cubic meters

Source: own compilation based on data obtained from the website: https://data.worldbank.org/ (as of 10.03.2020)

The data in Figure 3 show that Russia is undoubtedly the leader in terms of its natural gas reserves. Its reserves are about 1,688,228,000 cubic meters of gas, or about 24.3 percent of the world's reserves. Saudi Arabia holds about 4.2 percent of the world's gas reserves, or 294,205,000 cubic meters. It should be emphasized that the Middle Eastern countries, namely Saudi Arabia, Iran, Qatar, United Arab Emirates, Iraq and Kuwait, together hold about 2,757,292,000 cubic meters of gas, which is about 39.72 percent of the world's total reserves.

Then, for research purposes, Figure 4 summarizes the data of the countries that consumed the most gas in 2016.

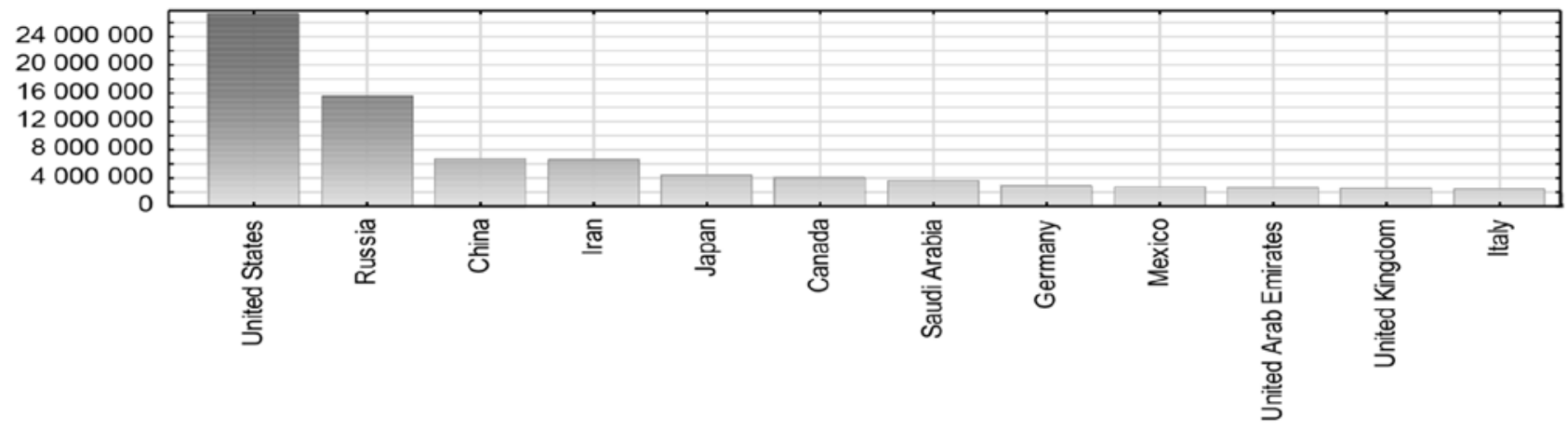

Figure 4: Bar chart of primary data on countries that consume the most gas annually in million cubic meters

Source: own compilation based on data from the website: https://data.worldbank.org/ (as of 10.03.2020)

The data presented in Figure 4 shows that the United States consumes the most gas during the period under consideration, which is about $27,243,858$ cubic meters, or 21.7 percent of the consumption of all countries in the world. In second place is Russia, which consumed 15,538,247 cubic meters of gas, or 12.4 percent of the consumption of all countries. Given its gas needs, Russia is self-sufficient for about 108 years, provided it does not sell. Saudi Arabia is in seventh place. It consumed about 3,614,137 cubic meters of gas in 2016, which is about $2.9 \%$ of its total consumption. It is self-sufficient like Russia, but for a period of about 81 years. The total natural gas reserves should be sufficient to meet the needs of the economies of individual countries for about 55 future years, assuming that gas consumption will be the same as in the considered 2016 and will not show an increasing or decreasing trend. Another important aspect in terms of international cooperation and influence on international decisions, if only on the price of oil or gas, is that Saudi Arabia does not have nuclear weapons and does not have as large an armament as Russia. Russia has the world's largest nuclear arsenal, including storing about 6490 warheads, with about 1600 deployed ready for use. It should also be noted that the Russians have produced the largest bomb at 50 megatons of TNT. Figures 5 and 6 provide a comparative analysis of the strategic armament of the armiesof Saudi Arabia and Russia. 


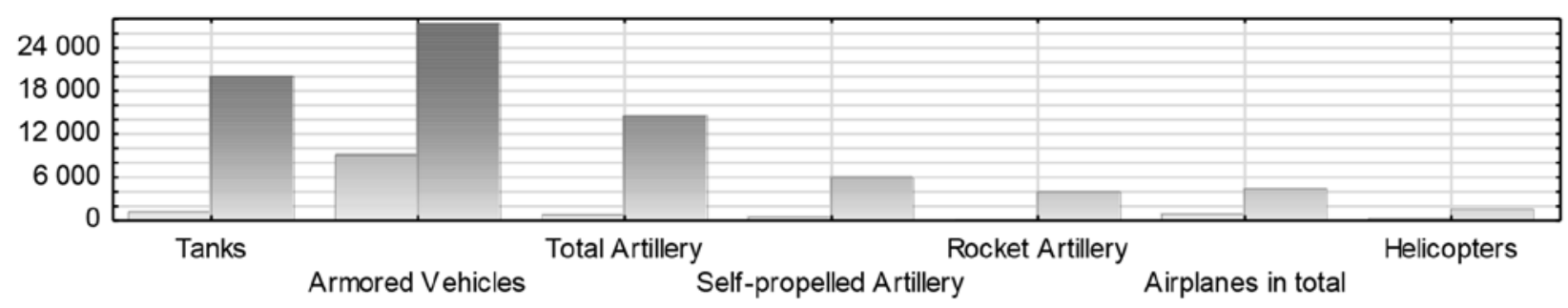

SA

RU

Figure 5: Bar chart of primary data on the number of essential armaments of the armies of Saudi Arabia and Russia

Source: own compilation based on data obtained from the website:

https://armedforces.eu/compare/country_Saudi_Arabia_vs_Russia (as of 16.03.2020)

The data in Figure 5 clearly show Russia's military superiority over Saudi Arabia.

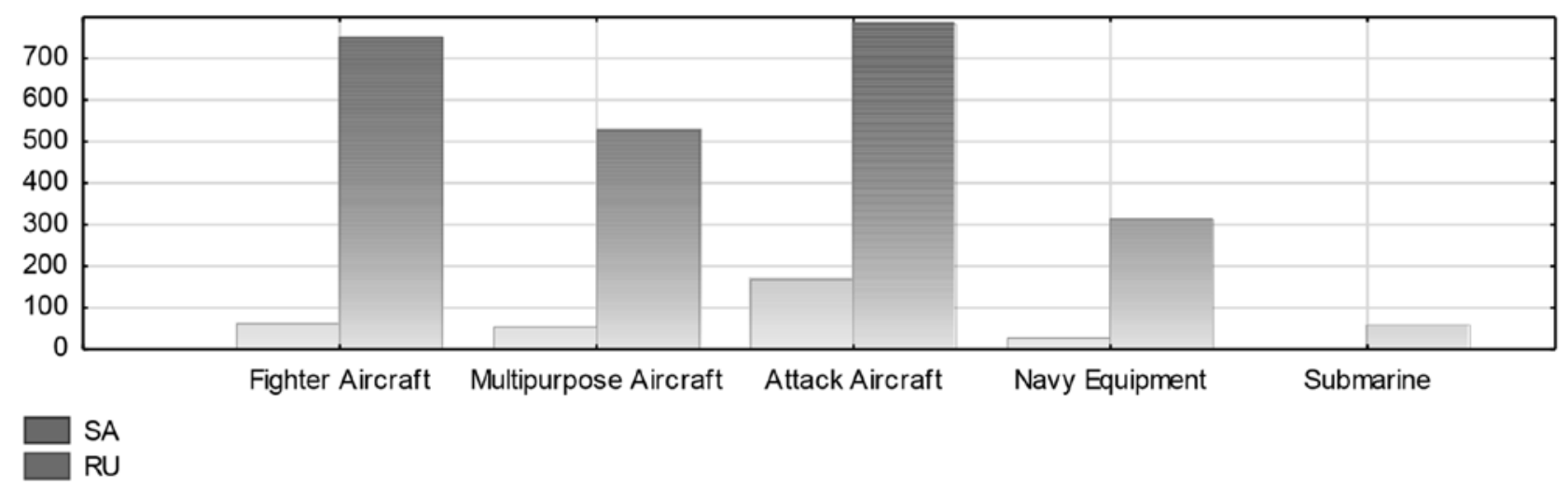

Figure 6: Bar chart of primary data on the number of essential armaments of the armies of Saudi Arabia and Russia

Source: own compilation based on data from the website: https://armedforces.eu/compare/country_Saudi_Arabia_vs_Russia (as of 16.03.2020) Russia's unambiguous military superiority over Saudi Arabia can also be seen in Figure 6.

\section{Evaluation of multidimensional data analysis}

A critical analysis of the literature and the authors' own knowledge shows that the potential for Russian-Saudi military cooperation is unrealized. Russia seeks to limit the influence of both Saudi Arabia and the United States in the Middle East region. This allows Saudi Arabia itself to not dictate world oil prices. The United States, on the other hand, due to the huge demand for this raw material, is forced to pursue such a policy in order to be guaranteed an appropriate price and continuity of supplies to meet its needs in this area. At the same time Russia and Saudi Arabia strive to maintain high oil prices, because its sale is the main source of their budget revenues. A serious threat to Saudi Arabia is Iran, with which Russia effectively cooperates in the military aspect. Also important is the point of contention between Russia and Saudi Arabia regarding the resolution of the ongoing armed conflict in Syria.

The conducted analysis clearly shows that Russia effectively influences Saudi Arabia. A manifestation of this effectiveness is that Saudi Arabia itself does not have the ability to dictate global commodity prices. It should also be emphasized that Russia in a way is a guarantor of ensuring and maintaining peace in the region of the Middle East, especially in countries with the largest resources of natural resources, including oil (Jurgilewicz et al., 2020). 


\section{Summary, conclusions}

The purpose of the study has been achieved. The impact of Russian policy on Saudi Arabia in terms of its attempt to dictate oil prices and its military policy in the Middle East region was examined. It has been concluded that Russia is effectively influencing Saudi Arabia. This is dictated by many aspects, which certainly include the continued military cooperation with Iran, which directly translates into a threat to Saudi Arabia from that country.

A further issue is the different views of Russia and Saudi Arabia on the resolution of the conflict in Syria. Undoubtedly, Russia's main objective in its relations with Saudi Arabia is the issue of influencing prices and seeking to make them as high as possible. Because of Russia's huge military potential and the policy it pursues in the Middle Eastern countries, its opinion on oil prices and other issues is important and taken into account. It should be emphasized that oil sales are the main source of Russia's budget revenues. Nevertheless, it should also be noted that now Russia's policy towards Saudi Arabia may change, and this is dictated by the coronavirus pandemic and lower global demand for oil.

\section{References:}

Jurgilewicz M. et al., Energy security of the Visegrad Group Countries in the natural gas sector, Journal of Security and Sustainability Issues Vol. 10(2), December 2020, s. 173-181.

Kozicki B., Waściński T., Brzeziński M., Lisowska A., Cost forecast in a shipping company, Transport Means, (1) 2018.

Legucka A., Russia's Cooperation with Saudi Arabia: Potential and Limitations (Współpraca Rosji z Arabią Saudyjską: potencjał i ograniczenia), Polski Instytut Spraw Międzynarodowych, Biuletyn, Nr 66 (1508), 2017.

Łuniewska M., Tarczyński W., Methods of multidimensional comparative analysis on the capital market (Metody wielowymiarowej analizy porównawczej na rynku kapitałowym), Warszawa, 2006.

Nermend K., Methods of multi-criteria and multi-dimensional analysis in decision support, (Metody analizy wielokryterialnej i wielowymiarowej we wspomaganiu decyzji), Warsaw 2017.

Nurzyńska A., Security of services in international passenger air transport, (Bezpieczeństwo usług w międzynarodowym transporcie lotniczym przewozów pasażerskich), Katowice 2016.

Satomi E., et al., Alocação justa de recuros de saúde escassos diante da pandemia de COVID-19. Considerações éticas", Einstein, São Paulo 18(2):1-5, April 2020, https://journal.einstein.br/article/fair-allocation-of-scarce-medical-resources-during-covid-19-pandemicethical-considerations/.

Trocki M., Project evaluation - concepts and methods (Ocena projektów - koncepcje i metody), Warsaw, 2013.

Zhu N., Zhang D., Wang W., Li, X., Yang B., Song J., A Novel Coronavirus from Patients with Pneumonia in China, 2019 , et al. 2020.01.24, New England Journal of Medicine. 383(8), 727-733. https://www.nejm.org/doi/10.1056/NEJMoa2001017

Grochot A., Koronawirus. What to Do When You Have Symptoms? (Coronavirus Co trzeba zrobić, kiedy zauważymy u siebie objawy?), https://twojezdrowie.rmf24.pl/choroby/news-koronawirus-co-trzeba-zrobic-kiedy-zauwazymy-u-siebie-objawy,nId,4294520\#crp_ state $=1$ (accessed: 10.03.2020).

Matuka A., COVID-19 Outbreak and US Economic Policy Uncertainty: An ARDL Approach, SSRN Electronic Journal, September 2020. https://papers.ssrn.com/sol3/papers.cfm?abstract_id=3685346

Pawel KĘPA, Rzeszów University of Technology, PL. Research interests: international security, policy, international relations. ORCID ID: 0000-0003-2306-8748

Bartosz KOZICKi, Military University of Technology, PL. Research interests: national security, internal security. ORCID ID: 0000-0001-6089-952X

This work is licensed under the Creative Commons Attribution International License (CC BY). $\mathrm{http}: / /$ creativecommons.org/licenses/by/4.0/ 